\title{
Suomi (koulutus)politiikan huipulla
}

EU:n puheenjohtajamaana Suomi on vuosituhannen viimeiset kuukaudet maailmanpolitiikan tai ainakin europolitiikan polttopisteessä. Opetusministeriö isännöi kaikkiaan 18:aa kahdeksalle eri paikkakunnalle hajajärjestettyä koulutuksen ja kulttuurin ongelmia ratkovaa tapahtumaa, ministeri-, virkamies- tai asiantuntijakokousta. Kaikkien neuvostojen, ministeritapaamisten, virallisten ja epävirallisten, ja politiikan teon ohella ohjelmaan kuuluu myös lukuisasti eri hallinnonalojen ongelmiin liittyviä konferensseja. Näistä erityisesti kaksi palvelee aikuiskouluttajien tarpeita.

$\mathrm{T}$ urussa syyskuussa järjestettävän konferenssin aiheena on elinikäinen oppiminen, vapaa sivistystyö ja kansalaisyhteiskunta. EU:n ensimmäisen polven vaihto-ohjelmissa oikeastaan vain COMETT yritysten ja oppilaitosten yhteistyön kautta kosketti aikuisopiskelijoita. Kun kirjava ohjelmien joukko toisessa vaiheessa koordinoitiin ammatillisen koulutuksen LEONARDO-ohjelmaksi ja yleissivistävän koulutuksen SOKRATES-ohjelmaksi, jossa avattiin väylät perusopetuksessa toimivienkin vaihdolle, aikuiskoulutus ja erityisesti vapaa sivistystyö jäivät vieläkin syrjään. Syyt ovat ymmärrettäviä. Vapaa sivistystyö käsitetään jäsenmaissa hyvinkin eri tavalla, ja se on organisoitunut niin moninaisesti, että luontevia vaihdon partnereita on ollut vaikea löytää. Sitä ei myöskään ole mielletty elimelliseksi osaksi koulutusjärjestelmää, ja näin se on jäänyt asialistalla taustalle. Elinikäisen oppimisen ajatuksen tunkiessa kansallisten koulutuspolitiikkojen hallitsevaksi strategiaksi aikuiskoulutuksen, mukaanluettuna vapaa sivistystyö, asema on alettu nähdä keskeisenä. Vuosille 2000-2006 tarkoitettu SOKRATES II sisältääkin oman "budjettirivin" ja toiminnon, joka on saanut osuvan nimen Grundtvig-toiminto.

Toiminnon tavoitteista voidaan mainita "toisen mahdollisuuden" antaminen koulutuksesta syrjäytyneille, aikuiskoulutustiedon ja innovaatioiden levittäminen jäsenmaissa, aikuiskouluttajien pätevyyden lisääminen, kieli- ja tukipalvelujen kehittäminen opiskelijoille ja koulutusta järjestäville, henkilövierailut ja -vaihdot sekä koulujärjestelmän ulkopuolella hankitun osaamisen legitimointi vahvistetuiksi kelpoisuuksiksi. Kun EU:1la ei ole mandaattia puuttua jäsenmaiden 
koulutukseen (läheisyysperiaate) eikä sillä ole omia koulutuslaitoksia, se ei voi varsinaisesti tehdä koulutuspolitiikkaa. Tärkeäksi toimintatavaksi koulutuspolitiikan muotoilussa onkin toimintaohjelmien ohella tullut yhteistyöverkostojen rakentaminen. Tähän Grundtvik-ohjelma antanee potkua ja Turun konferenssi eväitä jatkosuunnittelulle.

$\mathrm{T}$ oinen relevantti tapaaminen on Tampereella marraskuussa järjestettävä konferenssi koulutuksen ja työelämän yhteistyön uusista haasteista. Työn ja työelämän rakenteiden muutoksessa on käynyt selväksi, että ammatillisen osaamisen käsite on määriteltävä uudella tavalla ja että muodollinen koulutus ei yksin selviä osaamisen tuottamisesta ja ylläpitämisestä. Oman paineensa työssä oppimisen tekemiselle näkyväksi nostaa ensi vuoden alussa voimaan tuleva neuvoston päätös vuorotteluoppisopimuskoulutuksen edistämisestä eurooppalaisena järjestelmänä. Tarkoituksena on muodostaa kumppanuussuhteita oppilaitoksen ja toisessa jäsenmaassa sijaitsevien yritysten tai julkisten työnantajien kanssa. Yhdessä sovitaan vuorottelukoulutuksen sisällöstä, tavoitteista, kestosta, menetelmistä ja ohjauksesta. Työssä oppimisen todistamiseksi käyttöön otetaan formaatiltaan standardoitu opintokirja, europassi, johon kirjataan työssäoppimisen jaksot, jotka liikkuvan työntekijän tai opiskelijan kotimaan viranomaiset virallistavat oman tutkintojärjestelmänsä osaksi. Toistakymmentä vuotta kehitteillä ollut, formaalin koulutuksen todistuksia täydentävä elinikäinen opintokirja on vihdoinkin toteutumassa.

$\mathrm{O}$ n pantava merkille, että yhtenäistävä koulutuspolitiikka on voimistumassa unionissa. Opetusministerien kesäkuussa allekirjoittama Bolognan julistus pyrkii selvästi korkean asteen tutkintorakenteen yhtenäistämiseen kaksiportaiseksi perus- (undergraduate) ja jatkotutkinnoksi (graduate) sekä muutenkin koulutuksen yhteensopivuuden ja vertailtavuuden parantamiseen. Moni näkee julistuksen harmonisointipyrkimyksenä. Mahdollista on tulkita julistus myös siten, että se vauhdittaa ammattikorkeakoulu- ja yliopistotutkintojen suoraa rinnastamista, jopa yhdentämistä.

Reijo Raivola

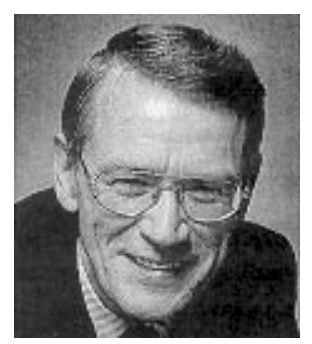

